\title{
PARTISIPASI ANGGOTA KELOMPOK TANI DALAM PROGRAM KAWASAN RUMAH PANGAN LESTARI DI DESA MARGA KAYA KECAMATAN JATI AGUNG KABUPATEN LAMPUNG SELATAN
}

\author{
(Participation of Members of Farmer Groups in Kawasan Rumah Pangan Lestari Program in Marga Kaya \\ Village Jati Agung District of South Lampung Regency)
}

Fitria Dwi Rahma Piska, Kordiana K Rangga, Dame Trully Gultom

Jurusan Agribisnis, Fakultas Pertanian, Universitas Lampung, Jl. Prof. Dr. Soemantri Brojonegoro No.1 Bandar Lampung 35141, e-mail: kordiyana.rangga@fp.unila.ac.id

\begin{abstract}
This study aims are to find out implementation of the Kawasan Rumah Pangan Lestari Program (KRPL), to know the level of community participation in the Program and the factors related to the participation. This study was conducted in November - December 2018 in the Marga Kaya Village Jati Agung Subdistrict South Lampung District. The method used was a survey method. The total of 46 respondents was used as samples by using proportional random sampling method. Correlation between variables were tested using Spearman Rank Correlation Test. KRPL is a home garden land use program by planting family medicinal plants and vegetables. The implementation of the KRPL program is the first year at the stage of growing members of farmer groups for funding of Rp. 15,000,000 in 2013. Some activities conducted in the program included nurseries, plot demonstrations, cultivating in yards, and assistance by extension agents. The second year, namely the development stage, the KRPL program that has been grown in the first year, will continue at the development stage. The third year is the stage of independence of the KRPL program that has developed the management of the KRPL. In this stage, the source of funds is obtained through self-help members of the group implementing the activities. The average participation rate of farmer group members in the program was 69.28 percent. Factors significantly related to the participation are knowledge about the program, education level, communication intensity, motivation level, and experience.
\end{abstract}

Keywords: participation, kawasan rumah pangan lestari program, farmers

\section{PENDAHULUAN}

Indonesia memiliki sumber daya hayati yang sangat kaya. Namun sebagian masyarakat masih belum menyadari adanya sumber daya yang tersedia dan tingkat konsumsi sebagian penduduk masih di bawah anjuran pemenuhan gizi. Salah satu upaya untuk meningkatkan ketahanan pangan dan gizi keluarga dapat dilakukan melalui lahan pekarangan yang dikelola oleh rumah tangga (Balai Pengkajian dan Pengembangan Teknologi 2011).

Salah satu upaya pemerintah untuk meningkatkan pendapatan dan produksi disektor pertanian adalah kegiatan pemanfaatan lahan pekarangan Kawasan Rumah Pangan Lestari (KRPL). Kawasan Rumah Pangan Lestari merupakan salah satu program kementerian pertanian yang diselenggarakan pada tahun 2012 sampai dengan sekarang (2019) dalam rangka optimalisasi lahan pekarangan yang ramah lingkungan dalam suatu kawasan. Kawasan Rumah Pangan Lestari dapat diwujudkan dalam satu wilayah antara lain wilayah Rukun Tetangga
(RT), Rukun Warga (RW), wilayah dusun atau desa (Badan Litbang Pertanian 2012)

Pelaksanaan kegiatan program KRPL di Provinsi Lampung sudah dilaksanakan mulai tahun 2012 di Kabupaten Pringsewu, Kabupaten Tulang Bawang, Lampung Selatan Kecamatan Natar dan Kabupaten Pringsewu pada tahun 2013, Kabupaten Tanggamus dan Kabupaten Pesawaran pada tahun 2014, tahun 2015 di Kota Bandar Lampung dan di Kota Metro tahun 2017.

Menurut Slamet dalam Suryono (2001), partisipasi masyarakat dalam pembangunan diartikan sebagai ikut sertanya masyarakat dalam pembangunan suatu program, memanfaatkan dan menikmati hasil-hasil dari program yang dijalankan. Masyarakat diharapkan dapat berpartisipasi dalam membangun serta menjaga lingkungan mereka berada dalam mensukseskan kegiatan pemanfaatan lahan pekarangan. Partisipasi masyarakat dalam program KRPL di Desa Marga Kaya merupakan keikutsertaan atau keterlibatan masyarakat terhadap kegiatan pemanfaatan lahan pekarangan 
untuk memenuhi pangan dan gizi keluarga masyarakat secara lestari. Dari hasil wawancara kepada anggota kelompok tani, masyarakat belum merasa ada perubahan maupun pemenuhan kebutuhan pangan dan gizi.

Tujuan dari penelitian adalah mengetahui pelaksanaan program KRPL, mengetahui tingkat partisipasi anggota kelompok tani dalam Program KRPL, menganalisis faktor-faktor yang berhubungan dengan tingkat partisipasi anggota dalam Program KRPL.

\section{METODE PENELITIAN}

Penelitian ini dilakukan di Desa Marga Kaya Kecamatan Jati Agung Kabupaten Lampung Selatan. Penentuan lokasi dilakukan secara sengaja (purposive) dengan pertimbangan bahwa Desa Marga Kaya merupakan desa yang anggota kelompok taninya paling banyak mengikuti program KRPL di Kecamatan Jati Agung Kabupaten Lampung Selatan, yaitu dari tahun 2013 sampai dengan sekarang (2019). Penelitian ini dilakukan pada bulan November-Desember 2018.

Data dalam penelitian ini diperoleh melalui wawancara langsung dengan menggunakan kuesioner dan didukung dengan data yang diperolah dari dinas dan instansi terkait. Variabel dalam penelitian ini terdiri dari dua variabel yaitu $\mathrm{X}$ dan Y. Variabel $\mathrm{X}$ adalah faktor-faktor yang behubungan dengan tingkat partisipasi anggota kelompok tani dalam Program KRPL. Variabel (Y) adalah partisipasi anggota kelompok tani.

Populasi berjumlah dari 325 orang yang tergabung dalam enam kelompok tani. Sampel diambil menggunakan rumus Sugiarto, dkk (2003) diperoleh sampel sebanyak 46 orang. Jumlah sampel dari setiap kelompok tani ditentukan menggunakan metode alokasi proporsional berdasarkan jumlah anggota setiap gapoktan. Metode analisis data yang digunakan pada penelitian ini adalah analisis deskriptif dan analisis inferensial menggunakan statistik nonparametrik korelasi Rank Spearman (Siegel 1997).

\section{HASIL PENELITIAN}

Program KRPL merupakan program pemanfaatan lahan pekarangan rumah dengan menanam tanaman toga, umbi-umbian dan tanaman sayuran. Pada awal pelaksanaan program, ibu-ibu setiap anggota kelompok tani diberikan bibit tanaman toga, umbi-umbian dan sayuran berbentuk polybag yang sudah ada di kebun bibit, selanjutnya mereka merawat tanaman tersebut hingga panen. Lahan anggota kelompok tani yang dimanfaatkan tidak hanya bagian depan rumah, tetapi lahan yang ada di samping atau belakang rumah.

Hasil yang didapat pada kegiatan pengelolaan pekarangan tidak hanya untuk dikonsumsi atau dijual, akan tetapi pengetahuan dalam membudidayakan pengetahuan. Penyuluh atau PPL mengadakan monitoring pada pelaksanaan KRPL tersebut secara berkala yaitu setiap bulan sekali di Desa Marga Kaya. Anggota kelompok tani yang terlibat kegiatan KRPL di Desa Marga Kaya terdiri dari enam anggota kelompok tani yaitu Lestari I, Mekar Sari IIA, Lestari II, Mekar Sari IIB, Lestari III, dan Mekar Sari I.

Berdasarkan hasil penelitian yang dilaksanakan, pemanfaatan penataan pekarangan merupakan salah satu kegiatan utama pada pelaksanaan program KRPL. Masing-masing anggota kelompok tani memanfaatkan pekarangan rumah yang kosong untuk ditanami sayuran, tanaman obat keluarga (toga), umbi-umbian dan tanaman buahbuahan. Lahan pekarangan yang dimanfaatkan tidak hanya bagian depan rumah, akan tetapi lahan pekarangan yang ada di samping atau belakang rumah.

\section{Partisipasi Dalam Fase Perencanaan}

Partisipasi dalam perencanaan kegiatan adalah keterlibatan anggota kelompok tani dalam perencanaan program KRPL. Pada penelitian ini, partisipasi dalam perencanaan kegiatan adalah ikut sertanya anggota kelompok tani dalam perencanaan program, ikut serta dalam pembentukan kelompok dan ikut serta dalam kegiatan sosialisasi mengenai tujuan kegiatan program KRPL.

Berdasarkan data lapangan, partisipasi dalam perencanaan kegiatan diklasifikasikan menjadi tiga kelas yaitu rendah, sedang dan tinggi. Partisipasi anggota kelompok tani dalam perencanaan program KRPL dapat dilihat pada Tabel 1. Ratarata sebaran tingkat partisipasi anggota kelompok tani dalam perencanaan program berada pada klasifikasi sedang yaitu sebesar 3,59 persen. Anggota kelompok tani mengumpulkan informasi mengenai potensi desa dalam bidang pertanian. Potensi yang ada di Desa Marga Kaya memiliki lahan pekarangan yang bisa dimanfaatkan untuk bercocok tanam. 
Tabel 1. Sebaran tingkat partisipasi anggota kelompok tani dalam perencanaan Program KRPL

\begin{tabular}{lllc}
\hline $\begin{array}{l}\text { Selang } \\
\text { Interval }\end{array}$ & Klasifikasi & $\begin{array}{l}\text { Jumlah } \\
\text { Responden } \\
\text { (orang) }\end{array}$ & $\begin{array}{c}\text { Persentase } \\
(\%)\end{array}$ \\
\hline $2,00-3,06$ & Rendah & 17 & 36,95 \\
$3,06-4,13$ & Sedang & 12 & 26,09 \\
$4,13-5,19$ & Tinggi & 17 & 36,96 \\
\hline Jumlah & 3,59 & 46 & 100,00 \\
Rata-rata & (sedang) & & \\
\hline
\end{tabular}

Kegiatan yang dilakukan dalam melakukan perencanaan pemanfaatan lahan pekarangan meliputi penentuan lokasi demplot. Lahan yang digunakan untuk demplot adalah milik anggota kelompok tani. Anggota kelompok tani mengikuti kegiatan sosialisasi mengenai maksud dan tujuan kegiatan yang kemudian berkoordinasi langsung dengan BPP Kecamatan Jati Agung Kabupaten Lampung Selatan.

\section{Partisipasi Dalam Fase Pelaksanaan}

Partisipasi dalam pelaksanaan kegiatan adalah keterlibatan anggota kelompok tani dalam pelaksanaan kegiatan program KRPL. Pada penelitian ini, partisipasi dalam pelaksanaan kegiatan program KRPL merupakan partisipasi anggota kelompok tani dalam memperoleh benih, partisipasi anggota kelompok tani dalam menerapkan pupuk yang diberikan dari dinas setempat dan keikutsertaan anggota kelompok tani.

Berdasarkan data yang diperoleh dari lapangan, tingkat partisipasi dalam kegiatan pelaksanaan diklasifikasikan menjadi tiga kelas yaitu rendah, sedang dan tinggi. Tingkat partisipasi dalam kegiatan pelaksanaan program KRPL dapat dilihat pada Tabel 2. Sebaran tingkat partisipasi anggota kelompok tani dalam pelaksanaan kegiatan program KRPL berada pada klasifikasi rendah yaitu sebesar 50 persen ( 23 orang).

Tabel 2. Sebaran tingkat partisipasi anggota kelompok tani dalam pelaksanaan kegiatan Program KRPL

\begin{tabular}{lllc}
\hline $\begin{array}{l}\text { Selang } \\
\text { Interval }\end{array}$ & Klasifikasi & $\begin{array}{l}\text { Jumlah } \\
\text { Responden } \\
\text { (orang) }\end{array}$ & $\begin{array}{c}\text { Persentase } \\
(\%)\end{array}$ \\
\hline $3,00-4,60$ & Rendah & 23 & 50,00 \\
$4,60-6,21$ & Sedang & 10 & 21,73 \\
$6,21-7,81$ & Tinggi & 13 & 28,26 \\
\hline Jumlah & 5,16 & 46 & 100,00 \\
Rata-rata & (sedang) & & \\
\hline
\end{tabular}

Anggota kelompok tani melakukan pembuatan rumah bibit dengan ukuran $5 \times 5$ meter dengan atap asbes dan dinding waring, pembuatan bibit yang berada di Desa Marga Kaya bertempat di pekarangan rumah ketua kelompok tani. Kelompok tani melakukan kegiatan pengolahan lahan seperti pembersihan lahan, penggemburan tanah, pemberian pupuk kompos yang dilakukan serentak dalam satu hari sesuai anjuran penyuluh. Setelah pengolahan lahan pekarangan dilaksanakan kemudian dilakukan pembuatan demplot pada lahan pekarangan.

Kegiatan penanaman yang dilakukan menggunakan komoditas tanaman sayuran yaitu sawi, kangkung, pakcoy, terong biru, cabe rawit, tomat. Anggota kelompok tani juga menanam komoditas umbi-umbian yaitu singkong dan mantang, komoditas tanaman buah-buahan yaitu pepaya, komoditas tanaman toga yaitu kunyit, jahe, lengkuas, dan temulawak. Pada saat penanaman, anggota kelompok tani memperhatikan kerataan penanaman, ketepatan jarak tanam dan keseimbangan jumlah bibit tanaman yang dianjurkan PPL. Lahan pekarangan yang telah ditanami kemudian diberikan pupuk untuk memaksimalkan hasil yang didapatkan, anggota kelompok tani menggunakan jenis pupuk organik dan urea. Penanaman yang telah dilaksanakan diperlukan pengendalian hama dan penyakit pada tumbuhan menggunakan pestisida alami.

\section{Partisipasi Dalam Fase Pemantauan Dan Evaluasi}

Partisipasi dalam pemantauan dan evaluasi program adalah keterlibatan anggota kelompok tani dalam memberikan penilaian sejauh mana program KRPL dapat dicapai. Sebaran tingkat partisipasi anggota kelompok tani dalam pemantauan dan evaluasi masuk pada klasifikasi tinggi yaitu sebesar 56,52 persen (26 orang).

Tabel 3. Sebaran tingkat partisipasi anggota kelompok tani dalam evaluasi kegiatan Program KRPL

\begin{tabular}{lllc}
\hline Selang Interval & Klasifikasi & $\begin{array}{l}\text { Jumlah } \\
\text { Responden } \\
\text { (orang) }\end{array}$ & $\begin{array}{c}\text { Persentase } \\
(\%)\end{array}$ \\
\hline $2,00-3,74$ & Rendah & 6 & 13,04 \\
$3,75-5,47$ & Sedang & 14 & 30,43 \\
$5,48-7,21$ & Tinggi & 26 & 56,52 \\
\hline Jumlah & 5,25 & 46 & 100,00 \\
Rata-rata & (sedang) & & \\
\hline
\end{tabular}


Partisipasi anggota kelompok tani dalam pemantauan dan evaluasi awal program adalah adalah mengenai perkembangan tanaman dan demplot. Anggota kelompok tani bersama-sama dengan penyuluh mengevaluasi mengenai masalahmasalah yang terdapat dalam pertumbuhan tanaman seperti adanya ulat penggangu dan daun tanaman menguning.

Kegiatan partisipasi dalam mengevaluasi program KRPL adalah keikutsertaan anggota kelompok tani dalam menilai jumlah anggota kelompok, menilai apakah kegiatan yang sudah dilaksanakan sesuai dengan perencanaan awal. Hal ini menunjukkan bahwa anggota kelompok tani mempunyai kemauan dan kemampuan yang tinggi untuk ikut dalam menilai atau mengevaluasi kegiatan program KRPL yang telah dilakukan.

\section{Partisipasi Dalam Fase Pemanfaatan Hasil}

Partisipasi dalam pemanfaatan hasil kegiatan adalah keterlibatan anggota kelompok tani dalam menerima hasil dari kegiatan yang dilakukan. Pada penelitian ini, partisipasi dalam pemanfaatan hasil yaitu berupa manfaat yang dirasakan anggota kelompok tani setelah menerapkan program KRPL. Berdasarkan data yang diperoleh dari lapangan tingkat partisipasi anggota kelompok tani dalam pemanfaatan hasil diklasifikasikan menjadi tiga kelas yaitu rendah, sedang dan tinggi. Tingkat partisipasi anggota kelompok tani talam pemanfaatan hasil program KRPL dapat dilihat pada Tabel 4.

Rata-rata tingkat partisipasi petani dalam pemanfaatan hasil sebesar 1,79 atau berada pada klasifikasi sedang. Manfaat dari program KRPL yang ada di Desa Marga Kaya yaitu lahan pekarangan yang ada lebih berdaya guna untuk membantu perekonomian setiap anggota kelompok tani yang ikut berpartisipasi.

Tabel 4. Sebaran tingkat partisipasi anggota kelompok tani dalam pemanfaatan hasil

\begin{tabular}{llcr}
\hline Selang Interval & Klasifikasi & $\begin{array}{c}\text { Jumlah } \\
\text { Responden } \\
\text { (orang) }\end{array}$ & $\begin{array}{r}\text { Persentase } \\
(\%)\end{array}$ \\
\hline $1,00-1,53$ & Rendah & 23 & 50,00 \\
$1,53-2,06$ & Sedang & 0 & 0,00 \\
$2,06-2,59$ & Tinggi & 23 & 50,00 \\
\hline Jumlah & 1,79 & 46 & 100,00 \\
Rata-rata & (sedang) & & \\
\hline
\end{tabular}

Anggota kelompok tani di Desa Marga Kaya telah membuat usaha rumahan dari hasil program KRPL yaitu mengembangkan singkong sebagai bahan pangan lokal yang diproses menjadi tepung singkong sebagai bahan untuk membuat kue kering dan oyek. Seluruh anggota kelompok tani ikut berpartisipasi dalam mengembangkan usaha rumahan tersebut. Hasil pemasaran dari hasil olahan ini kemudian dimasukkan ke kas kelompok. Kegunaan kas dapat dipinjamkan ke anggota kelompok tani yang memerlukan kebutuhan atau modal usaha yang diperlukan.

\section{Pengetahuan tentang Program KRPL}

Pengetahuan tentang program Kawasan Rumah Pangan Lestari adalah pengetahuan yang dimiliki responden mengenai program KRPL. Indikator pengetahuan tentang program yaitu responden mengetahui siapa yang memberikan program, mengetahui tujuan dari pemanfaatan pekarangan dan mengetahui jenis pupuk yang diberikan dalam program KRPL.

Tingkat pengetahuan tentang program KRPL berada pada klasifikasi tinggi yaitu sebesar 50 persen (23 orang). Hal ini menunjukkan bahwa tingkat pemahaman anggota kelompok tani terhadap siapa yang memberikan program, tujuan dari pemanfaatan pekarangan dan jenis pupuk yang diberikan.

Anggota kelompok tani telah mengetahui perencanaan program KRPL yaitu melakukan perencanaan meliputi penentuan lokasi demplot, mengetahui pelaksanaan program, melakukan pembuatan rumah bibit dengan ukuran $5 \times 5$ meter dengan atap asbes dan dinding waring, pembuatan bibit bertempat di pekarangan rumah ketua kelompok tani dan kelompok tani melakukan kegiatan pengolahan lahan seperti pembersihan lahan, penggemburan tanah, pemberian pupuk kompos hingga panen.

Tabel 5. Sebaran tingkat pengetahuan tentang program KRPL

\begin{tabular}{llrr}
\hline Selang Interval & Klasifikasi & $\begin{array}{c}\text { Jumlah } \\
\text { Responden } \\
\text { (orang) }\end{array}$ & $\begin{array}{c}\text { Persentase } \\
(\%)\end{array}$ \\
\hline $6,66-9,87$ & Rendah & 15 & 32,60 \\
$9,88-13,08$ & Sedang & 8 & 17,39 \\
$13,09-16,29$ & Tinggi & 23 & 50,00 \\
\hline Jumlah & 12,53 & 46 & 100,00 \\
Rata-rata & (sedang) & & \\
\hline
\end{tabular}




\section{Frekuensi Kegiatan Penyuluhan}

Frekuensi mengikuti kegiatan penyuluhan adalah jumlah kehadiran petani dalam mengikuti kegiatan penyuluhan, khususnya penyuluhan tentang program KRPL. Indikator frekuensi kegiatan penyuluhan yaitu berapa kali anggota kelompok tani mengikuti kegiatan penyuluhan dalam satu bulan dan apakah adanya manfaat yang dirasakan dari kegiatan penyuluhan dalam program KRPL. Pengukuran indikator tersebut dilakukan dengan daftar pertanyaan dengan menggunakan skor 1-3 berdasarkan data di lapangan.

Berdasarkan data yang diperoleh dari lapangan, frekuensi kegiatan penyuluhan diklasifikasikan menjadi tiga kelas yaitu rendah, sedang dan tinggi. Hasil penelitian menunjukkan frekuensi kegiatan penyuluhan dalam program dapat dilihat pada Tabel 6.

Frekuensi kegiatan penyuluhan berada dalam klasifikasi tinggi yaitu sebesar 67,39 persen (31 orang). Rata-rata frekuensi kegiatan penyuluhan adalah 4,82 dan masuk pada klasifikasi tinggi. Hal ini menunjukkan bahwa sebagian besar anggota kelompok tani telah mengikuti kegiatan penyuluhan di Desa Marga Kaya yang dilakukan setiap bulan. Kegiatan penyuluhan dilakukan di kantor UPT BPP Kecamatan Jati Agung atau di Balai Desa. Petani sangat merasakan manfaat dari adanya kegiatan penyuluhan yang dilakukan. Responden sangat antusias dalam mengikuti kegiatan penyuluhan, anggota kelompok tani mendapat banyak informasi atau pengetahuan tentang program KRPL dari penggunaan benih yang baik dan pemeliharaan tanaman yang baik.

\section{Kekosmopolitan}

Kekosmopolitan merupakan keluasan wawasan dan keterbukaan petani terhadap berbagai informasi dari luar dirinya. Indikator variabel kekosmopolitan yaitu apakah anggota kelompok tani pernah mengadakan pertemuan atau anjangsana dengan tokoh masyarakat, berapa kali anggota kelompok tani menonton telivisi setiap bulan dan apakah anggota kelompok tani mengetahui adanya acara pertanian di televisi

Berdasarkan data yang diperoleh dari lapangan, variabel kekosmopolitan diklasifikasikan menjadi tiga kelas yaitu rendah, sedang dan tinggi. Tingkat kekosmopolitan anggota kelompok tani dapat dilihat pada Tabel 7.
Tabel 6. Sebaran frekuensi kegiatan penyuluhan dalam satu bulan

\begin{tabular}{llcr}
\hline $\begin{array}{l}\text { Selang } \\
\text { Interval }\end{array}$ & Klasifikasi & $\begin{array}{c}\text { Jumlah } \\
\text { Responden } \\
\text { (orang) }\end{array}$ & $\begin{array}{c}\text { Persentase } \\
\mathbf{( \% )}\end{array}$ \\
\hline $2,00-3,39$ & Rendah & 14 & 30,43 \\
$3,40-4,79$ & Sedang & 1 & 2,17 \\
$4,80-6,18$ & Tinggi & 31 & 67,39 \\
\hline Jumlah & 4,82 & 46 & 100,00 \\
Rata-rata & (Tinggi) & & \\
\hline
\end{tabular}

Tabel 7. Sebaran tingkat kekosmopolitan kelompok tani dalam Program KRPL

\begin{tabular}{llcc}
\hline $\begin{array}{l}\text { Selang } \\
\text { Interval }\end{array}$ & Klasifikasi & $\begin{array}{c}\text { Jumlah } \\
\text { Responden } \\
\text { (orang) }\end{array}$ & $\begin{array}{c}\text { Persentase } \\
(\%)\end{array}$ \\
\hline $3,00-4,94$ & Rendah & 17 & 39,96 \\
$4,95-6,89$ & Sedang & 12 & 26,08 \\
$6,90-8,848$ & Tinggi & 17 & 36,96 \\
\hline Jumlah & 6,18 & 46 & 100,00 \\
Rata-rata & (Sedang) & & \\
\hline
\end{tabular}

Sebaran tingkat kekosmopolitan masuk pada klasifikasi rendah yaitu sebesar 39,96 persen (17 orang). Rata-rata kekosmopolitan responden sebesar 6,18 atau masuk pada klasifikasi sedang. Berdasarkan hasil penelitian menunjukkan bahwa anggota kelompok tani yang mengikuti kegiatan pertemuan atau anjangsana dengan tokoh anggota kelompok tani dalam rangka menambah informasi tentang pertanian untuk dirinya sendiri yang dilakukan sebanyak empat kali dalam sebulan.

Anggota kelompok tani kurang aktif mengikuti kegiatan pertemuan atau anjangsana dengan tokoh anggota kelompok tani dalam mencari informasi mengenai pertanian. Adanya informasi pertanian yang diperoleh oleh anggota kelompok tani memberikan dampak yang positif sehingga memudahkan anggota kelompok tani dalam pelaksanaan kegiatannya.

\section{Intensitas Komunikasi}

Intensitas komunikasi merupakan frekuensi dan keaktifan anggota kelompok tani dalam mencari informasi mengenai usahatani yang dilakukan, baik dengan sesama pengurus atau anggota melalui teknologi informasi dan komunikasi. Indikator intensitas komunikasi yaitu kendala apa saja yang anggota kelompok tani temui selama melaksanakan program, seberapa sering anggota kelompok tani mengajukan usul, saran, masukan pada setiap pertemuan, anggota kelompok tani aktif atau tidak pada kegiatan penyuluhan dan 
apakah penyuluh membantu anggota kelompok tani dalam melaksanakan program. Intensitas komunikasi anggota kelompok tani dapat dilihat pada Tabel 8.

Sebaran intensitas komunikasi masuk pada klasifikasi rendah yaitu sebesar 60,87 perrsen (28 orang). Rata-rata skor intensitas komunikasi responden sebesar 5,12 dan masuk pada klasifikasi sedang. Berdasarkan hasil penelitian, pada saat pelaksanaan kegiatan yang dilakukan penyuluh anggota kelompok tani jarang mengajukan usul, saran, masukan kemudian pertanyaan pada saat pelaksanaan kegiatan sedang berlangsung.

Kegiatan penyuluhan yang dilaksanakan untuk menunjang pelaksanaan program KRPL sangat dibutuhkan oleh anggota kelompok tani, agar program KRPL yang telah dilaksanakan dapat memberikan dampak yang positif. Peran penyuluh sangat penting pada kegiatan program KRPL yang dilakukan, penyuluh membantu anggota kelompok tani dalam mendapatkan informasi-informasi dan membantu anggota kelompok tani dalam melaksanakan kegiatan program KRPL.

\section{Tingkat Motivasi}

Tingkat Motivasi merupakan sesuatu yang mendorong anggota kelompok tani untuk melakukan tindakan. Indikator tingkat motivasi yaitu apakah anggota kelompok tani mengikuti kegiatan-kegiatan pemanfaatan lahan pekarangan (optimalisasi lahan pekarangan, penyediaan bantuan benih, penyediaan bantuan pupuk, pendampingan) program KRPL dan bagaimana penilaian anggota kelompok tani terhadap kegiatan program KRPL. Pengukuran tingkat motivasi dilakukan dengan daftar pertanyaan dengan menggunakan skor 1-3 berdasarkan data di lapangan. Lebih jelas dapat dilihat pada Tabel 9.

Sebaran tingkat motivasi masuk pada klasifikasi tinggi yaitu sebesar 52,17 persen (24 orang). Hal ini menunjukkan bahwa, anggota kelompok tani mengikuti kegiatan-kegiatan yang dilakukan dalam pemanfaatan lahan dan merasakan adanya keuntungan dari program yang dilakukan. Anggota kelompok tani rajin melakukan kegiatan pertemuan penyuluh lapangan dalam rangka menambah informasi tentang pertanian untuk mendukung kegiatan program KRPL.
Tabel 8. Sebaran intensitas komunikasi anggota kelompok tani dalam Program KRPL

\begin{tabular}{llcr}
\hline $\begin{array}{l}\text { Selang } \\
\text { Interval }\end{array}$ & Klasifikasi & $\begin{array}{c}\text { Jumlah } \\
\text { Responden } \\
\text { (orang) }\end{array}$ & $\begin{array}{c}\text { Persentase } \\
(\%)\end{array}$ \\
\hline $3,00-4,99$ & Rendah & 28 & 60,87 \\
$5,00-6,98$ & Sedang & 10 & 21,73 \\
$6,99-8,97$ & Tinggi & 8 & 17,39 \\
\hline Jumlah & 5,12 & 46 & 100,00 \\
Rata-rata & (Sedang) & & \\
\hline
\end{tabular}

Tabel 9. Sebaran tingkat motivasi anggota kelompok tani di Desa Marga Kaya

\begin{tabular}{llrr}
\hline $\begin{array}{l}\text { Selang } \\
\text { Interval }\end{array}$ & Klasifikasi & $\begin{array}{c}\text { Jumlah } \\
\text { Responden } \\
\text { (orang) }\end{array}$ & $\begin{array}{c}\text { Persentase } \\
(\%)\end{array}$ \\
\hline $2,00-3,52$ & Rendah & 16 & 34,78 \\
$3,53-5,05$ & Sedang & 6 & 13,04 \\
$5,06-6,58$ & Tinggi & 24 & 52,17 \\
\hline Jumlah & 5,25 & 46 & 100,00 \\
Rata-rata & (Sedang) & & \\
\hline
\end{tabular}

Anggota kelompok tani terdorong untuk melakukan pemanfaatan lahan pekarangan seperti optimalisasi lahan. Rangkaian kegiatan-kegiatan KRPL ini mengharuskan anggota kelompok tani untuk turut aktif dalam setiap kegiatan. Rangkaian-rangkaian kegiatan yang dilaksanakan anggota kelompok tani aktif mengikuti tiga sampai lima kegiatan yang diberikan oleh penyuluh, sehingga memberikan manfaat yang dapat menunjang anggota kelompok tani dalam pelaksanaan program. KRPL dapat membantu mengurangi biaya pengeluaran konsumsi pangan. Kegiatan pemanfaatan lahan pekarangan menyebabkan anggota kelompok tani menjadi lebih produktif dalam kegiatan sehari-harinya. Kegiatan-kegiatan pemanfaatan lahan pekarangan menguntungkan setiap anggota kelompok tani yang ikut serta dalam pelaksanaan program KRPL yang dapat mengurangi biaya pengeluaran seharihari, sehingga anggota kelompok tani menjadi termotivasi mengembangkan pemanfaatan lahan pekarangannya.

\section{Pengalaman Berusahatani}

Pengalaman berusahatani adalah kemampuan atau keterampilan petani dalam pengambilan keputusan untuk mengatasi kendala-kendala selama menjalankan kegiatan berusahatani, tingkat pengalaman berusahatani dapat dilihat berdasarkan daftar pertanyaan mengenai pengetahuan dan pengambilan keputusan dalam mengatasi kendalakendala selama melaksanakan kegiatan usaha tani. 
Tabel 10. Sebaran tingkat pengalaman berusahatani anggota kelompok tani

\begin{tabular}{llcc}
\hline $\begin{array}{l}\text { Selang } \\
\text { Interval }\end{array}$ & Klasifikasi & $\begin{array}{c}\text { Jumlah } \\
\text { Responden } \\
\text { (orang) }\end{array}$ & $\begin{array}{c}\text { Persentase } \\
(\%)\end{array}$ \\
\hline $4,00-6,67$ & Rendah & 16 & 34,78 \\
$6,68-9,34$ & Sedang & 11 & 23,91 \\
$9,35-12,01$ & Tinggi & 19 & 41,31 \\
\hline Jumlah & 8,64 & 46 & 100,00 \\
Rata-rata & (Sedang) & & \\
\hline
\end{tabular}

Indikator pengalaman berusahatani yaitu anggota kelompok tani mengetahui dan menerapkan kegiatan dalam program KRPL, mengetahui mengenai program KRPL, mengetahui tentang keselamatan kerja dan memahami dan menerapkan standar keamaan serta keselamatan kerja. Pengalaman berusahatani diklasifikasikan menjadi tiga kelas yaitu rendah, sedang dan tinggi. Lebih jelasnya dapat dilihat padaTabel 10 .

Tabel 10 menunjukkan bahwa pengalaman berusahatani berada pada klasifikasi tinggi yaitu sebesar 41,31 persen (19 orang). Petani yang sudah berpengalaman dalam berusahatani diharapkan dapat meningkatkan partisipasi petani dalam program KRPL di Desa Marga Kaya Kecamatan Jati Agung Kabupaten Lampung Selatan. Hal ini menunjukkan bahwa pengetahuan dalam berusahatani berpengaruh terhadap pelaksanaan program.

Anggota kelompok tani lebih cepat mengambil keputusan untuk memecahkan permasalahan yang dihadapi dalam bercocok tanam seperti, penanganan penyakit dan hama yang menyerang tumbuhan dengan pestisida alami, sehingga dapat mencegah kerugian. Pelaksanaan kegiatan program KRPL juga perlu memperhatikan standar keamanan dan keselamatan dalam bekerja. Setiap anggota kelompok tani yang ikut serta dalam pelaksanaan program KRPL telah mengetahui tentang keselamatan kerja dan hal-hal apa saja yang perlu diperhatikan untuk meminimalisir kecelakaan dalam bekerja, sehingga tidak menimbulkan kerugian akhirnya.

\section{Pengujuan Hipotesis}

\section{Variabel-variabel (X) yang berhubungan dengan partisipasi anggota kelompok tani dalam program KRPL (Y)}

Hubungan antara variabel X (tingkat pengetahuan tentang program, frekuensi kegiatan penyuluhan, kekosmopolitan, intensitas komunikasi, tingkat motivasi dan pengalaman berusahatani) dengan variabel Y (partisipasi anggota kelompok tani dalam program KRPL) dianalisis dengan menggunakan statistika non parametrik uji korelasi Rank Spearman. Hasil pengujian statistik antara terhadap faktor-faktor yang berhubungan dengan partisipasi anggota kelompok tani dalam program KRPL dapat dilihat pada Tabel 11.

Hasil pengujian hipotesis hubungan antara pengetahuan tentang Program KRPL dengan partisipasi anggota kelompok tani dalam Program KRPL menggunakan uji korelasi Rank Spearman diperoleh nilai koefisien korelasi sebesar 0,383 dan tingkat signifikasi $0,009<\alpha(0,05)$, maka dapat diambil keputusan untuk menerima $\mathrm{H}_{1}$, artinya terdapat hubungan yang nyata antara tingkat pengetahuan tentang program KRPL dengan partisipasi anggota kelompok tani. Hasil penelitian ini sejalan dengan penelitian Triana (2017) yang menyimpulkan bahwa tingkat pengetahuan berhubungan nyata dengan partisipasi anggota kelompok tani.

Hasil pengujian hipotesis antara frekuensi kegiatan penyuluhan dengan partisipasi anggota kelompok tani didapat nilai koefisian korelasi sebesar 0,553 dan tingkat signifikasi $0,000<\alpha(0,05)$, maka dapat diambil keputusan untuk menerima $\mathrm{H}_{1}$, artinya terdapat hubungan yang nyata antara frekuensi kegiatan penyuluhan dengan partisipasi anggota kelompok tani dalam program KRPL.

Tabel 11. Hasil analisis faktor-faktor yang berhubungan dengan partisipasi anggota kelompok tani dalam program KRPL.

\begin{tabular}{|c|c|c|c|c|}
\hline No. & Variabel X & $\begin{array}{c}\text { Variabel } \\
\mathrm{Y}\end{array}$ & $\begin{array}{l}\text { Koefisien } \\
\text { korelasi } \\
(r s)\end{array}$ & $\begin{array}{l}\text { Sig. } \\
(2- \\
\text { tailed) }\end{array}$ \\
\hline 1 & $\begin{array}{l}\text { Tingkat } \\
\text { Pengetahuan } \\
\text { tentang program } \\
\text { KRPL }\end{array}$ & & $0,383^{* *}$ & 0,009 \\
\hline 2 & $\begin{array}{l}\text { Frekuensi } \\
\text { kegiatan } \\
\text { penyuluhan }\end{array}$ & $\begin{array}{l}\text { Tingkat } \\
\text { partisipasi } \\
\text { petani }\end{array}$ & $0,553^{* *}$ & 0,000 \\
\hline 3 & Kekosmopolitan & terhadap &,$- 224^{\mathrm{tn}}$ & 0,135 \\
\hline 4 & $\begin{array}{l}\text { Intensitas } \\
\text { komunikasi }\end{array}$ & $\begin{array}{l}\text { program } \\
\text { KRPL }\end{array}$ & $0,509^{* *}$ & 0,000 \\
\hline 5 & $\begin{array}{l}\text { Tingkat } \\
\text { motivasi }\end{array}$ & & $0,400^{* *}$ & 0,006 \\
\hline 6 & $\begin{array}{l}\text { Pengalaman } \\
\text { berusahatani }\end{array}$ & & $0,388^{* *}$ & 0,008 \\
\hline
\end{tabular}


Hasil penelitian ini sejalan dengan penelitian Rizki (2018) yang menyimpulkan bahwa frekuensi berhubungan nyata dengan partisipasi anggota kelompok tani.

Hasil pengujian hipotesis antara tingkat kekosmopolitan dengan partisipasi anggota kelompok tani didapat nilai koefisian korelasi sebesar -,124 dengan tingkat signifikasi 0,135> $>\alpha$ $(0,05)$, maka dapat diambil keputusan untuk menolak $\mathrm{H}_{1}$, artinya terdapat hubungan yang tidak nyata antara tingkat kekosmopolitan dengan partisipasi anggota kelompok. Hasil penelitian ini tidak sejalan dengan penelitian Anggraini (2019) yang menyimpulkan bahwa tingkat kekosmopolitan berhubungan nyata dengan partisipasi anggota kelompok tani.

Kurangnya tingkat kekosmopolitan disebabkan oleh rendahnya keaktifan responden mengikuti kegiatan pertemuan atau anjangsana dengan tokoh anggota kelompok tani dalam mencari informasi mengenai pertanian. Adanya informasi pertanian yang diperoleh oleh anggota kelompok tani memberikan dampak yang positif, sehingga memudahkan anggota kelompok tani dalam pelaksanaan kegiatannya, khususnya program KRPL.

Hasil pengujian hipotesis antara intensitas komuniksi dengan partisipasi anggota kelompok tani didapat nilai koefisien korelasi sebesar 0,509 dengan tingkat signifikasi $0,000<\alpha(0,05)$, maka dapat diambil keputusan untuk menerima $\mathrm{H}_{1}$, artinya terdapat hubungan nyata antara intensitas komunikasi dengan partisipasi anggota kelompok tani. Hasil penelitian ini sejalan dengan penelitian Antika (2017) yang menyimpulkan bahwa intensitas komunikasi berhubungan nyata dengan partisipasi anggota kelompok tani.

Hasil pengujian hipotesis antara motivasi dengan partisipasi anggota kelompok tani didapat nilai koefisien korelasi sebesar 0,400 dengan tingkat signifikasi $0,006<\alpha(0,05)$, maka dapat diambil keputusan untuk menerima $\mathrm{H}_{1}$, artinya terdapat hubungan yang nyata antara motivasi dengan partisipasi anggota kelompok tani. Hasil penelitian ini sejalan dengan penelitian Maulidiawati (2018) yang menyimpulkan bahwa tingkat motivasi berhubungan nyata dengan partisipasi anggota kelompok tani.

Hasil pengujian hipotesis antara pengalaman berusahatani dengan partisipasi anggota kelompok tani didapat nilai koefisien korelasi sebesar 0,388 dengan tingkat signifikasi $0,008<\alpha(0,05)$, maka dapat diambil keputusan untuk menerima $\mathrm{H}_{1}$, artinya terdapat hubungan yang nyata antara pengalaman berusahatani dengan partisipasi anggota kelompok tani.

\section{KESIMPULAN}

Program KRPL merupakan program pemanfaatan lahan pekarangan rumah dengan menanam tanaman tanaman obat keluarga (toga), buah dan tanaman sayuran. Pelaksanaan program KRPL yaitu tahun pertama pada tahap penumbuhan anggota kelompok tani mendapatkan bantuan dana sebesar Rp15.000.000 pada tahun 2013. Kegiatan yang terdapat dalam program KRPL meliputi: a) pembangunan kebun bibit, b) pembuatan demplot, c) pengembangan lahan pekarangan dan pendampingan oleh penyuluh. Tahun kedua yaitu tahap pengembangan, program KRPL yang telah ditumbuhkan pada tahun pertama, akan dilanjutkan pada tahap pengembangan. Tahun ketiga yaitu tahap kemandirian program KRPL yang telah mengembangkan pengelolaan KRPL tidak lagi mendapatkan alokasi dana untuk KRPL yang telah dilaksanakan, sumber dana didapat melalui swadaya anggota kelompok pelaksana kegiatan, dan pemerintah pusat hanya melakukan monitoring dan pendampingan KRPL sedangkan untuk pemeliharaan selanjutnya diserahkan kepada anggota kelompok sasaran KRPL. (2) tingkat partisipasi anggota kelompok tani dalam program adalah sebesar 69,28 persen. Partisipasi petani dalam perencanaan sebesar 69,17 persen, partisipasi dalam pelaksanaan adalah sebesar 66,06 persen, partisipasi petani dalam pemantauan sebesar 72,81 persen dan partisipasi petani dalam pemanfaatan hasil adalah sebesar 69,11 persen, dan (3) Faktor-faktor yang berhubungan dengan partisipasi anggota kelompok tani terhadap program adalah pengetahuan tentang program, intensitas komunikasi, tingkat motivasi, dan pengalaman berusahatani. Kekosmopolitan tidak berhubungan dengan tingkat partisipasi.

\section{DAFTAR PUSTAKA}

Anggraini R. 2019. Partisipasi petani dan keberhasilan program pengembangan usaha pangan masyarakat (PUPM) di Kecamatan Palas Kabupaten Lampung Selata. JIIA, 7 (1) : 113-119. http://jurnal.fp.unila.ac.id/ index.php/JIA/article/view/1526. September 2019]. 
Antika YA. 2017. Tingkat partisipasi anggota P3A dalam Program Pengembangan Jaringan Irigasi (PJI) di Kelurahan F ajar Esuk Kecamatan Pringsewu Kabupaten Pringsewu. JIIA, 5 (3): 335-343. http://jurnal.fp.unila.ac.id/index.php/JIA/arti cle/view/1526. [24 Agustus 2019].

Balai Pengkajian dan Pengembangan Teknologi Pertanian. 2011. Petunjuk Pelaksanaan Pengembangan Model Kawasan Rumah Pangan Lestari. Balai Pengkajian dan Pengembangan Teknologi Pertanian. Bogor.

Maulidiawati D. 2018. Partisipasi petani dalam upsus pajale di Kecamatan Rawa Jitu Selatan Kabupaten Tulang Bawang. JIIA, 6 (1): 65-71. http://jurnal.fp.unila.ac.id/index. php/JIA/article/view/1526. [24 Agustus 2019].

Rizki HA. 2018. Partisipasi anggota kelompok tani dalam program upaya khusus padi jagung kedelai (UPSUS PAJALE) di Kecamatan
Metro Barat Kota Metro. JIIA, 7 (1): 99105. http://jurnal.fp.unila.ac.id/index.php/ JIA/article/view/1526. [28 September 2019].

Siegel. 1994. Statistik Non parametrik untuk Ilmu-ilmu Sosial. PT Gramedia Pustaka Utama. Jakarta.

Sugiarto, D Siagian, LT Sunaryanto, dan DS Oetomo. 2003. Teknik Sampling. PT. Gramedia Pustaka Utama. Jakarta.

Suryono A. 2001. Ekonomi Politik Pembangunan dalam Perspektif Teori Ilmu Sosial. UM Press. Universitas Negeri Malang. Malang.

Triana RS. 2017. Partisipasi petani dalam program upaya khusus peningkatan produksi padi, jagung dan kedelai (UP2PJK) di Kecamatan Seputih Raman Kabupaten Lampung Tengah. JIIA, 5 (4): 446-452. Http://jurnal. fp.Unila.ac.id/index.php/jia/article/view/152 6. [1 Oktober 2019]. 